\title{
Aspects of Metal-YSZ Electrode Kinetics Studied using Model Electrodes
}

\section{Graves, Christopher R.; Ebbesen, Sune; Mogensen, Mogens Bjerg}

\section{Published in:}

E C S Transactions

Link to article, DOI:

10.1149/1.3205739

Publication date:

2009

Document Version

Publisher's PDF, also known as Version of record

Link back to DTU Orbit

Citation (APA):

Graves, C. R., Ebbesen, S., \& Mogensen, M. B. (2009). Aspects of Metal-YSZ Electrode Kinetics Studied using Model Electrodes. E C S Transactions, 25(2), 1945-1955. https://doi.org/10.1149/1.3205739

\section{General rights}

Copyright and moral rights for the publications made accessible in the public portal are retained by the authors and/or other copyright owners and it is a condition of accessing publications that users recognise and abide by the legal requirements associated with these rights.

- Users may download and print one copy of any publication from the public portal for the purpose of private study or research.

- You may not further distribute the material or use it for any profit-making activity or commercial gain

- You may freely distribute the URL identifying the publication in the public portal

If you believe that this document breaches copyright please contact us providing details, and we will remove access to the work immediately and investigate your claim 


\title{
Aspects of Metal-YSZ Electrode Kinetics Studied Using Model Electrodes
}

\author{
Christopher Graves $^{\mathrm{a}, \mathrm{b}}$, Sune D. Ebbesen ${ }^{\mathrm{a}}$, Mogens Mogensen ${ }^{\mathrm{a}}$ \\ ${ }^{a}$ Fuel Cells and Solid State Chemistry Division, Risø National Laboratory for \\ Sustainable Energy, The Technical University of Denmark, 4000 Roskilde, Denmark \\ ${ }^{\mathrm{b}}$ Lenfest Center for Sustainable Energy, and Department of Earth and Environmental \\ Engineering, Columbia University, New York, New York 10027, USA
}

The electrode kinetics of oxidation and reduction of $\mathrm{H}_{2} / \mathrm{H}_{2} \mathrm{O}$ and $\mathrm{CO} / \mathrm{CO}_{2}$ at the metal/yttria stabilized zirconia (YSZ) interface were studied using model metal wire electrodes contacting polished YSZ pellets. The intent was to probe the reaction mechanisms by comparing the same reactions using different metals $(\mathrm{Ag}, \mathrm{Au}, \mathrm{Cu}$, $\mathrm{Ni}, \mathrm{Pd}$, and $\mathrm{Pt}$ ) under identical conditions relevant to fuel cell and electrolysis cell operation (e.g. including $50 \% \mathrm{H}_{2} / \mathrm{H}_{2} \mathrm{O}$ and $50 \%$ $\mathrm{CO} / \mathrm{CO}_{2}$ ). Impedance spectra were measured at open-circuit voltage and under polarization, and polarization sweeps were performed. The gas composition and temperature were varied to examine how the electrochemical measurements varied, to facilitate identifying the electrode rate-limiting processes. Possible mechanisms that may explain these and other details are discussed.

\section{Introduction}

The solid oxide cell (SOC) appears to have an important role to play in a sustainable energy future; as a fuel cell it can provide clean electricity from fossil energy resources and as an electrolysis cell it can store renewable and nuclear energy as clean portable fuels. While significant progress has been made in improving the efficiency and durability of both types of SOCs, a better understanding of the electrode reaction mechanisms would help in identifying ways to improve them further, both from the standpoints of designing new electrodes and of understanding the mechanisms by which the cells degrade.

The present work focuses on the reaction mechanisms at the negative-electrode. The negative electrode most often used is a porous ceramic-metal (cermet) composite composed of an interpenetrating network of nickel and yttria-stabilized zirconia (Ni/YSZ) particles. The electrochemical performance of this material is excellent for both fuel cell $\left(\mathrm{H}_{2}\right.$ and $\mathrm{CO}$ oxidation) and electrolysis $\left(\mathrm{H}_{2} \mathrm{O}\right.$ and $\mathrm{CO}_{2}$ reduction) operation. To characterize the reaction mechanisms that take place at the $\mathrm{Ni} / \mathrm{YSZ}$ interface, geometrically simplified model electrodes such as point-contact and pattern or felt electrodes, which are thought to act as single particle interfaces in a porous cermet electrode, can be employed (1). Many workers have studied $\mathrm{H}_{2}$ oxidation at Ni/YSZ by performing electrochemical impedance spectroscopy and/or polarization sweeps at a variety of conditions, systematically varying the supplied gas composition and the operating temperature and observing how the electrochemical response varies.

Despite all the work that has been done, the detailed kinetics of the electrode reactions are not well known (2). Little work has been done comparing the same 
reactions using different metals, even though this may be a good way to examine the kinetics of reactions occurring at the metal/YSZ interface. This work makes a comparative characterization of the electrode kinetics of several metals ( $\mathrm{Ag}, \mathrm{Au}, \mathrm{Cu}, \mathrm{Ni}$, $\mathrm{Pd}$, and $\mathrm{Pt}$ ) under identical conditions, using model wire electrodes contacting a YSZ pellet electrolyte.

In comparison to studies with model negative-electrodes using some of the same metals (a brief review follows), this study examines the electrochemical behavior of the metals at open circuit and under polarization, in systematically varied temperatures and gas compositions, including $\mathrm{H}_{2} \mathrm{O}$ - and $\mathrm{CO}_{2}$-rich gas atmospheres relevant to high reactant conversion during electrolysis or fuel cell operation. By including the metal as another variable, the aim is to gain a better understanding of the reaction mechanisms for oxidation and reduction of $\mathrm{H}_{2} / \mathrm{H}_{2} \mathrm{O}$ and $\mathrm{CO} / \mathrm{CO}_{2}$ at metal-YSZ interfaces.

\section{Prior Work}

A number of studies, using a variety of cell geometries, have been carried out with the intention of elucidating the reaction mechanisms. Point-contact electrodes are often a metal wire, either bent or melted to a ball-shaped end. Primarily Ni (3-15), but also sometimes Pt $(6,10,12,13)$, Au $(6,10)$, and $\mathrm{Ag}(6)$, have been used. Others have investigated $\mathrm{Ni}$ (16-20) and Pt (21) pattern electrodes and the differences between multiple geometries including patterns, meshes, and porous (all-metal; not cermet) Ni electrodes (16, 22-25). Many different metals ( $\mathrm{Au}, \mathrm{Co}, \mathrm{Fe}, \mathrm{Mn}, \mathrm{Ni}, \mathrm{Pd}, \mathrm{Pr}, \mathrm{Rh}$, and $\mathrm{Ru}$ ) were included in one study that used porous metal electrodes (26).

The reaction mechanisms have proven very difficult to determine. A number of possibilities have been proposed to explain experimental findings $(2,5)$. Attempts have also been made to derive impedance models from chemical rate equations $(9,12,16)$ and fit them to the data. One reason that it may be difficult to put together a clear picture is the lack of consistency in the reported data: contradictory results have been reported for a given geometry and for different geometries. For example, the number of impedance processes that have been identified for simple Ni point electrodes at similar temperature ranges varies from 1 to 3 . The polarization resistance normalized to the three-phase boundary (TPB; the Ni/YSZ/gas interface) length has been reported to vary by 2 orders of magnitude (11). In some cases $\mathrm{Ni}$ and $\mathrm{Pt}$ were found to have nearly the same electrochemical activity (6) while in others they were very different (21). Finally, oxidation of $\mathrm{H}_{2}$ on $\mathrm{Ni}$ has been reported as several times faster than $\mathrm{CO}$ oxidation in some Ni electrode studies (27), while in others they have been reported as nearly equal (28). While different electrode geometries and test set-ups might be able to explain some cases, it has become clear that impurities may be playing a large role in the inconsistencies, by complicating the interpretation of data and even by changing the reaction mechanism $(2,14,29-32)$. Specific relevant points from electrode kinetics literature will be further addressed below.

\section{Experimental}

Cells with a metal wire electrode contacting an $8 \mathrm{~mol} \% \mathrm{YSZ}$ electrolyte pellet (approximately $8 \mathrm{~mm}$ diameter and $3 \mathrm{~mm}$ thick) with a porous Pt-paste counter electrode were assembled in a single-atmosphere custom test rig. The test set-up was similar to 
that used in (15). A pseudo-three-electrode set-up was used, with the relatively large counter electrode expected to contribute negligible resistance and therefore serving as reference electrode.

The YSZ pellets were fabricated from Tosoh TZ-8Y powder. The powder was used as-received and uniaxially pressed $(187 \mathrm{MPa})$ followed by cold isostatic pressing (250 $\mathrm{MPa}$ ) for $30 \mathrm{~s}$ each. The resulting pellets were sintered at $1550^{\circ} \mathrm{C}$ for $2 \mathrm{~h}$ in air. One side of the pellets were then ground and polished in several steps, ending with $1 \mu \mathrm{m}$ diamond paste. Finer polishing was also tried on 2 pellets and this showed no effect on the impedance data; the measurements were reproducible with or without the extra polishing. AFM scans of the surface showed a smooth topography with a small concentration of holes. The other side of each pellet was lightly ground. The pellets were cleaned in ethanol in an ultrasonic bath. The unpolished side was then painted with Pt paste.

The metal wires had the following diameters and purity: $\mathrm{Ni}, 0.5 \mathrm{~mm}, 99.999 \%$ (Puratronic, Johnson Matthey); Cu, 0.5 mm, 99.999\% (Puratronic, Johnson Matthey); Ag, $0.3 \mathrm{~mm}$, purity unknown; Au, $0.3 \mathrm{~mm}$, purity unknown; Pd, $0.5 \mathrm{~mm}, 99.95 \%$; Pt, $0.5 \mathrm{~mm}$, 99.95\% (Ögussa). The wires were cut and bent approximately $1 \mathrm{~cm}$ from the end, to form a round tip. Some Ni wires were annealed and electropolished as described in ref. (15). These wires had a smooth surface. However, Ni wires used without the electropolishing step showed similar impedance. Therefore, and since it would be difficult to similarly smoothen the other metals by electropolishing, all metals were simply heat-treated in a reducing atmosphere at $600^{\circ} \mathrm{C}$ after bending, to clean the surface of organic material. The bent tip was examined in SEM or optical microscope. The metal wires were then cleaned ultrasonically in ethanol.

The test rig was first cleaned of any stray particles by carefully applying compressed air. Four cells were assembled in the test rig in a laminar air flow chamber to try to avoid contamination. Weights of 200-210 g were applied to each cell to make a stable contact (33). The rig was then heated to an initial temperature of $1000^{\circ} \mathrm{C}$ or $850^{\circ} \mathrm{C}$ (for the tests that included silver, to stay below the melting point of silver) in $9 \% \mathrm{H}_{2} / 91 \% \mathrm{~N}_{2}$ and switched to $3.6 \% \mathrm{H}_{2} \mathrm{O} / 96.4 \% \mathrm{H}_{2}$ upon arriving at the initial temperature. The gas flows during this time and during the gas variations were set such that the total was $4.6 \mathrm{~L} / \mathrm{h}$. Impedance spectra (IS) were then continuously measured at open-circuit voltage (OCV) for each of the 4 cells. IS measurements used 9 to 13 points per decade, from $1 \mathrm{MHz}$ to 5 or $100 \mathrm{mHz}$, with an AC RMS amplitude of $30 \mathrm{mV}$, using a Solartron 1255B+1287 or a Gamry Reference 600 . The series resistance $\left(R_{S}\right.$; the high-frequency intercept with the real axis) was monitored during and after heat-up to the initial temperature, while the contact area expanded due to the metal creep.

Electrochemical impedance spectroscopy at OCV at varying temperature (700$\left.1000^{\circ} \mathrm{C}\right)$ and gas composition $\left(\mathrm{CO} / \mathrm{CO}_{2} / \mathrm{Ar}\right.$ and $\left.\mathrm{H}_{2} / \mathrm{H}_{2} \mathrm{O} / \mathrm{Ar}\right)$ was employed to "fingerprint" the electrochemical performance of the metal-YSZ interfaces. Time was allowed for the cells to stabilize at each condition, measuring impedance spectra at OCV during the stabilization times. Since it was found that the electrodes degrade over time, the temperature variation at $50 \% \mathrm{H}_{2} \mathrm{O} / \mathrm{H}_{2}$ and $50 \% \mathrm{CO}_{2} / \mathrm{CO}$ was performed first, before the other gas variations, for the latter half of the cells tested. Potential sweeps were then performed, as well as impedance under polarization. Before each IS measurement under 
polarization, the desired polarization was first held for 5 minutes of DC bias chronoamperometrically.

After the test, the cells were disassembled and the electrode was lifted off the electrolyte surface. Both surfaces were examined in the SEM to obtain the final contact area and perimeter (TPB length).

Analysis of IS employed the method of condensing the impedance data by representing it with an equivalent circuit model. Transformation of the data to a distribution function of relaxation times (DRT) (34) was first performed to facilitate identifying the number of processes, and after fitting the data to the equivalent circuit model the simulated spectra from the fitted model was also transformed to a DRT and compared with the DRT of the original data. This enabled a more directed approach towards deciding on the model and then checking that the summit frequencies of the circuit elements corresponded to DRT peaks for the fit. Simple equivalent circuits composed of serial RQ elements were used, where R is a resistor and Q is a constant phase element.

\section{$\underline{\text { Initial Stabilization }}$}

\section{Results and Discussion}

During the first 50 hours at the, initial temperature $\left(850-1000^{\circ} \mathrm{C}\right), \mathrm{R}_{\mathrm{S}}$ decreased logarithmically for each cell and stabilized to within $15 \%$ of the final value that was measured after 200-700 hours. This was observed for each metal, as has been observed for $\mathrm{Ni}$ in the literature (31). The Newman relation (35)

$$
r=\frac{1}{4 \cdot \sigma \cdot R_{S}}
$$

has been shown to approximate the contact radius for point-contact electrodes on solid electrolytes with dimensions on the same order of magnitude as those used in these tests. Therefore, the creep of the metal wires which resulted in the initial growth of the contact area was mostly complete by hour 50. Most metals continued to creep slowly during the remainder of the tests. Pt crept relatively little compared to the rest.

\section{Data Normalization and Reproducibility}

Since the reaction sites have been linked to the TPB $(4,19,22)$, the TPB length (TPBL) may be a useful metric to normalize resistances (6). Whereas the contact area has a different meaning than the nominal area usually discussed in regards to porous electrodes, it is a useful metric to handle capacitance across the metal-YSZ contact. The contact area and perimeter (TPBL) measured from SEM micrographs of the flattened area of the metal wire (

Figure 1) agreed with the areas on the YSZ surface that exhibited differences in topography relative to the smooth surface outside the contact area $(11,14,29-31)$. Areas and perimeters calculated using the Newman relation with the final $R_{S}$ value from a test were lower than the SEM-measured values. The perimeter was often rough and significantly longer than that corresponding to a perfect circle. Correction factors were developed and used to estimate the contact area and perimeter during the test. The details of this procedure will appear in a full paper about this work. 
Using these normalizations and corrections, the length-specific polarization resistances $\left(\mathrm{LSR}_{\mathrm{P}}\right)$ of the cells were found to be reproducible, e.g. the relative standard deviation of $\mathrm{LSR}_{\mathrm{P}}$ between electrodes of the same material was less than $20 \%$ for $5 \mathrm{Ni}$ electrodes (including both electropolished and rough $\mathrm{Ni}$ electrodes) and less than $5 \%$ for $2 \mathrm{Cu}$ electrodes.
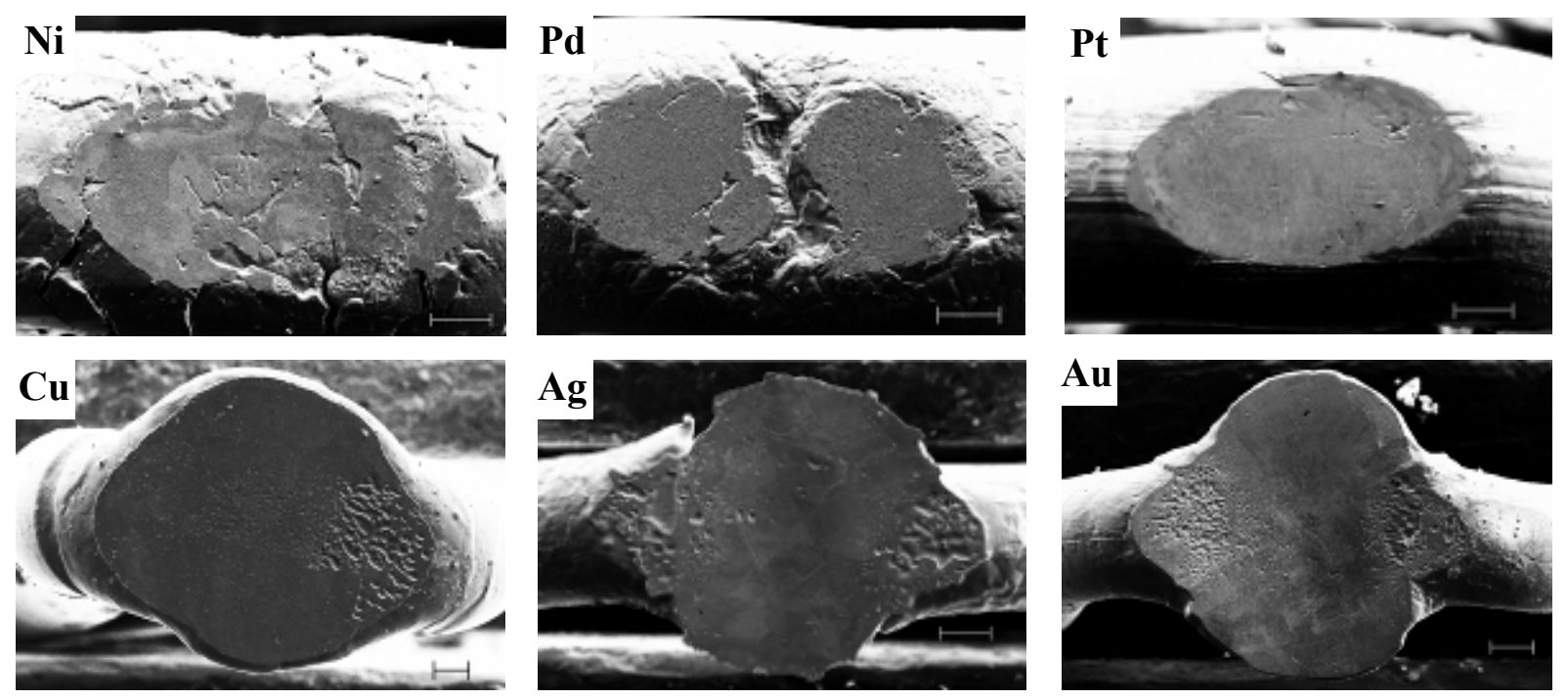

Figure 1. SEM micrographs of the flattened contact areas of representative wires of each metal. The scale bar shown in each is 100 microns. The smooth electropolished Ni wires are not shown. Large pieces of YSZ electrolyte were sometimes attached (not shown). The 3 lowest melting point metals $(\mathrm{Cu}, \mathrm{Ag}, \mathrm{Au})$ crept the most, resulting in the largest contact areas. Both Pd wires formed a crack when bent, which did not heal, resulting in 2 separated contact areas.

\section{Impedance Spectroscopy at OCV}

The procedure for fitting the impedance spectra demanded a circuit model composed of 3 serially-connected RQ elements, $L R(R Q)_{1}(R Q)_{2}(R Q)_{3}$, to achieve a fit with minimal error. The inductance L, usually associated to artifacts of the set-up, was minor in comparison to the magnitudes of the cell impedance, so most fits were performed without $\mathrm{L}$ and by discarding the high frequency range at which $\mathrm{L}$ contributed (which was much higher than any contributions from the cell response). For the $\mathrm{Ni}$ electrodes at $1000{ }^{\circ} \mathrm{C}$, the high-frequency arc 1 had n-values (for the constant phase element) close to unity $(>0.97)$. For the mid-frequency arc $2, n$ was around 0.95 . For the low-frequency arc $3, n$ was around 0.73 . The n-values were therefore constrained to these values during the fits presented in

Figure 2. Sometimes a fourth small high-frequency arc was found (visible in

Figure $2 \mathrm{~b}$ ), which contributed $<1 \%$ to the total impedance. This can likely be ascribed to the porous Pt counter electrode: a symmetrical cell with this electrode painted on both sides of an $8 \mathrm{YSZ}$ pellet was tested and the magnitudes and summit frequency of the impedance response agrees well with this minor arc. The fitted data was compared to the distribution of relaxation times of the original data ( 
Figure 2c) as described earlier. The fitted data represent the distribution well, supporting the validity of the fit.

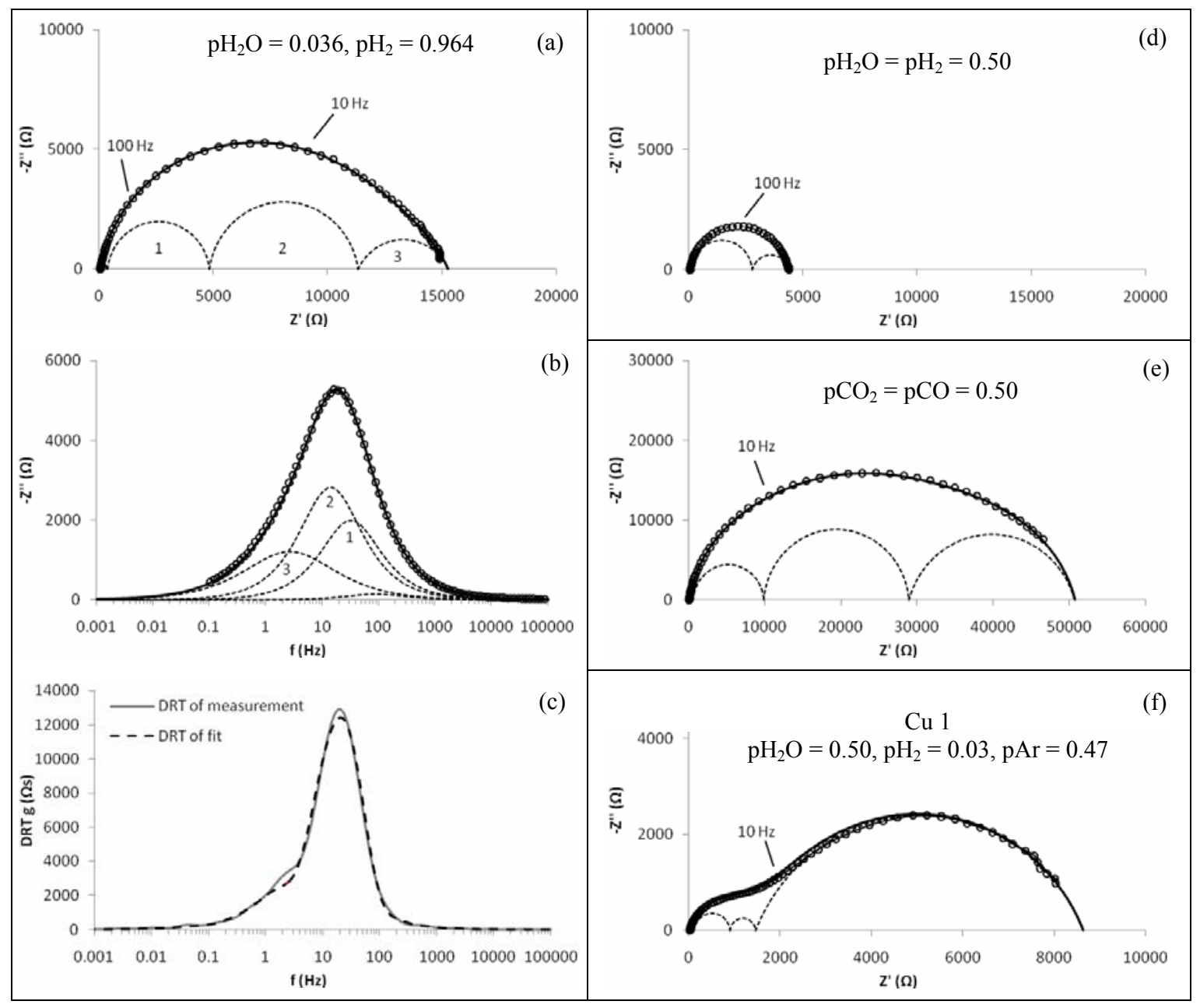

Figure 2. Various impedance spectra fitted to the equivalent circuit model, for cell Ni 1 at $1000^{\circ} \mathrm{C}$ at various conditions (a-e) and on cell $\mathrm{Cu} 1$ at $1000^{\circ} \mathrm{C}$ in one condition (f).

On the Ni electrode, it appears that an increase in $\mathrm{pH}_{2} \mathrm{O}$ causes a decrease in the impedance of the lower-frequency RQ elements, so much so that one process becomes negligible (

Figure $2 \mathrm{~d}$ ). A change to a gas composition of $50 \% \mathrm{CO}_{2} / \mathrm{CO}$ seems to enlarge all three processes (

Figure 2e). These changes are also apparent in the frequency domain (not shown). In some conditions, the three processes appear more separated (

Figure 2f).

The decrease in $\mathrm{R}_{\mathrm{P}}$ with increasing $\mathrm{pH}_{2} \mathrm{O}$ might be due to gas concentration resistances associated with the set-up, although such contributions are expected to be negligible for point electrode tests $(36,37)$. Such processes should not be thermally activated, but all three processes appear to have a strong and similar temperature dependence (Figure 3c). Other observations further support the conclusion that gas 
concentration processes are not represented in the arcs. The arcs might correspond to charge transfer, adsorption of the reactants and surface diffusion. Adsorption and surface diffusion would likely be affected by the gas composition and the metal. The $\mathrm{pH}_{2} \mathrm{O}$ observations suggest that for $\mathrm{Ni}$ some of these processes are activated by $\mathrm{H}_{2} \mathrm{O}$, as has been reported $(3,4,7,23)$.
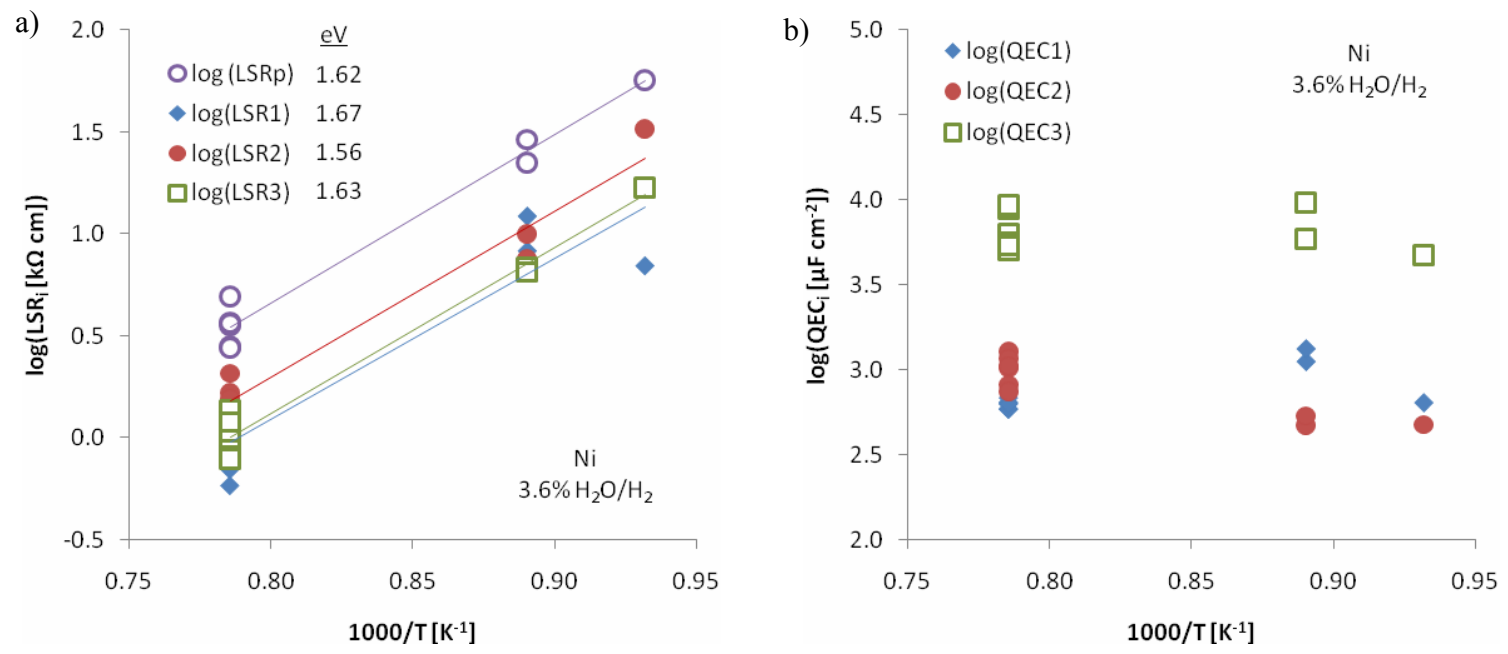

Figure 3. Arrhenius plots of LSR (a) and quasi-equivalent capacitances (b) associated with the fitted impedance processes which contribute to $\mathrm{R}_{\mathrm{P}}$ for cell $\mathrm{Ni} 1$, in $3.6 \% \mathrm{H}_{2} \mathrm{O} / \mathrm{H}_{2}$. The activation energy $\left(E_{a}\right)$ of $R_{P}$ and the contributing processes is $\sim 1.6 \mathrm{eV}$, which agrees with literature for coarse simplified geometries in this temperature range $(7,22)$.
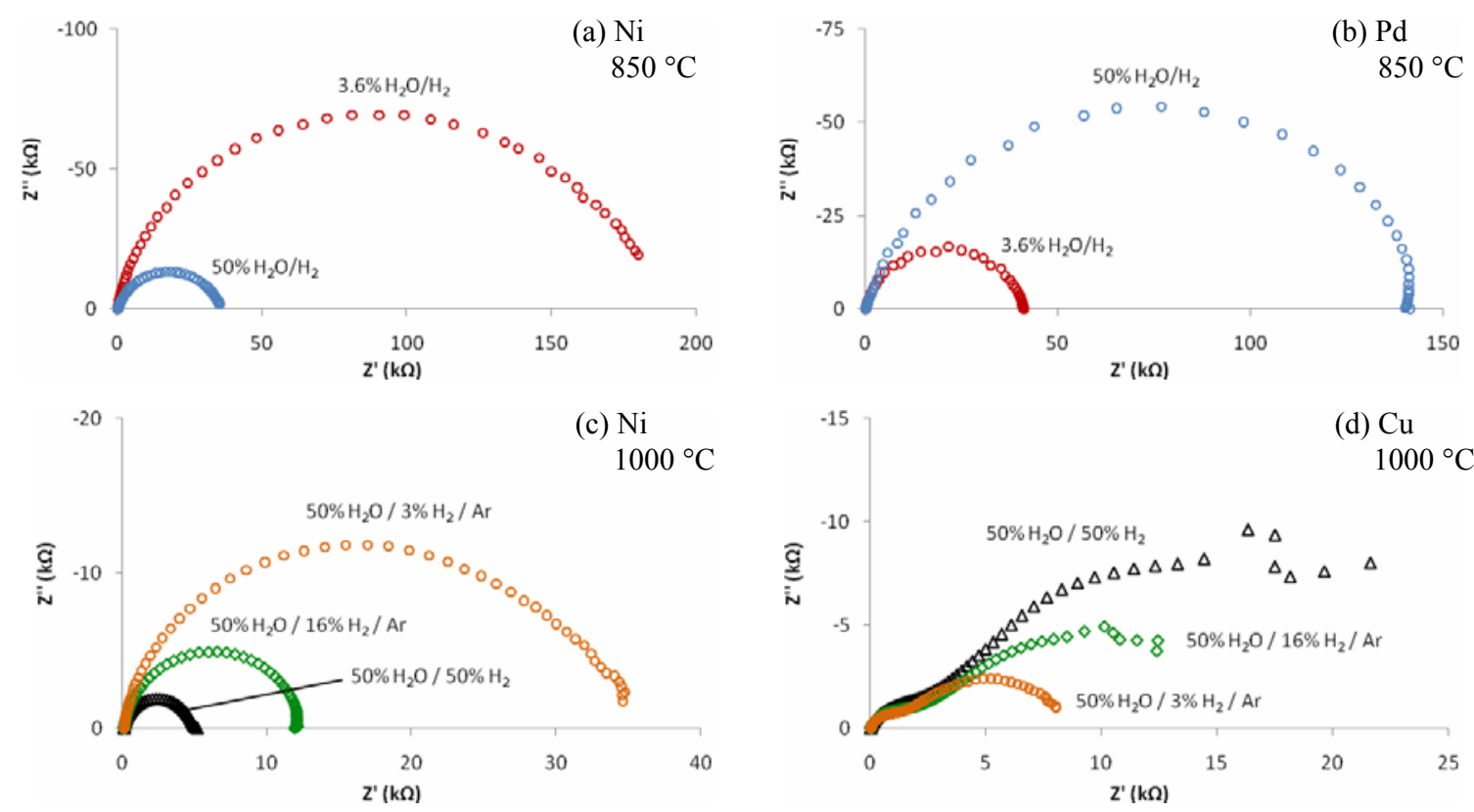

Figure 4. Comparison of impedance spectra recorded under the same conditions for $\mathrm{Ni}$ and $\mathrm{Pd}(\mathrm{a}-\mathrm{b})$ and for $\mathrm{Ni}$ and $\mathrm{Cu}(\mathrm{c}-\mathrm{d})$. For $\mathrm{Cu}$, the fluctuations are not measurement noise.

Pd exhibits the opposite behavior: $\mathrm{R}_{\mathrm{P}}$ increases with an increase in $\mathrm{pH}_{2} \mathrm{O}$. The impedance reponse of $\mathrm{Ni}$ and $\mathrm{Pd}$ are compared in Figure $4 \mathrm{a}-\mathrm{b}$. As with $\mathrm{Ni}, \mathrm{R}_{\mathrm{P}}$ decreases for the $\mathrm{Cu}$ electrode with a change from $\sim 4 \% \mathrm{H}_{2} \mathrm{O} / \mathrm{H}_{2}$ to $50 \% \mathrm{H}_{2} \mathrm{O} / \mathrm{H}_{2}$. However, another gas variation that holds $\mathrm{pH}_{2} \mathrm{O}$ at 0.5 and increasingly dilutes the balance $\mathrm{H}_{2}$ with argon 
increases $R_{P}$ significantly for $\mathrm{Ni}$ but decreases for $\mathrm{Cu}$ (Figure $4 \mathrm{c}-\mathrm{d}$ ). The activation energies of $R_{P}$ differ for the different metals, and sometimes depend on the gas composition (Figure 5). Clearly, impedance data show that the behavior of the different metals is very different in the same conditions, suggesting different reaction mechanisms. Then, the electrocatalytic activities may be more complicated than a single correlated property of the metals could describe $(26,38)$.
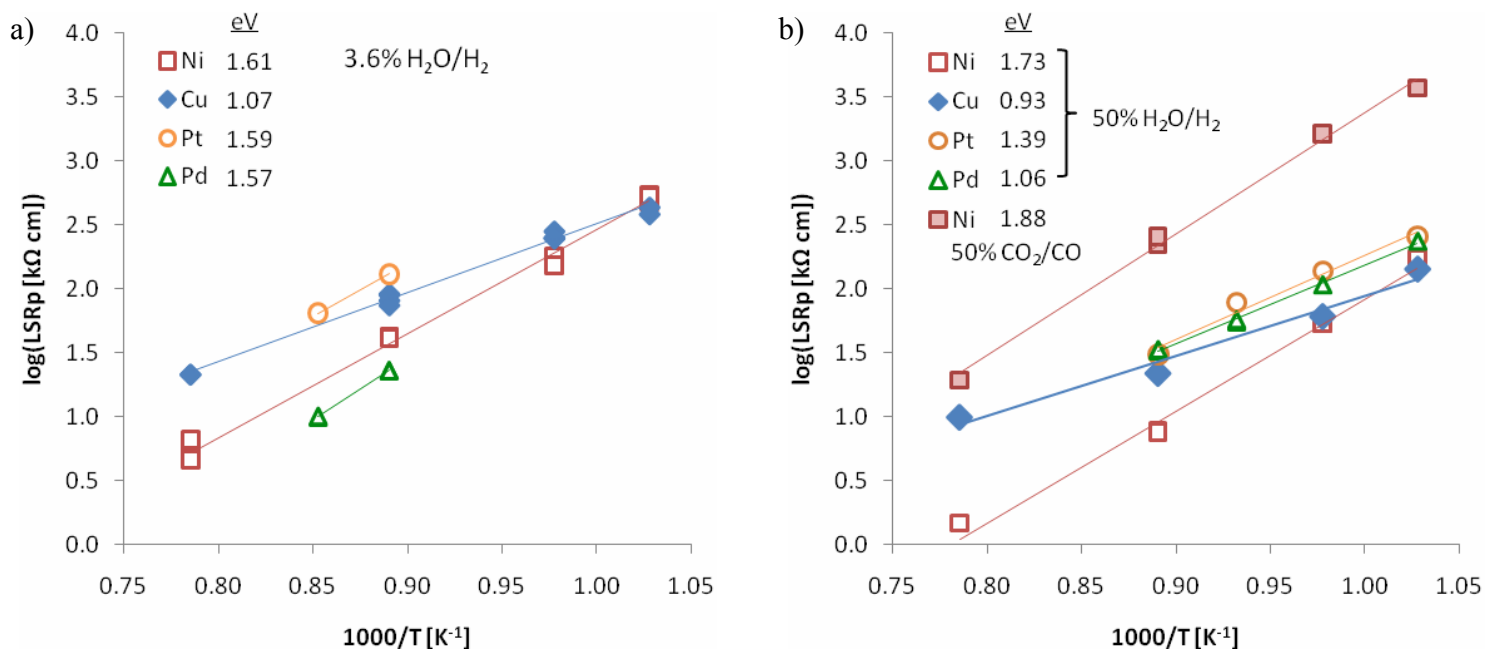

Figure 5. Arrhenius plots of the total $\mathrm{R}_{\mathrm{P}}$ for various metals in $3.6 \% \mathrm{H}_{2} \mathrm{O} / \mathrm{H}_{2}$ (a) and $50 \%$ $\mathrm{H}_{2} \mathrm{O} / \mathrm{H}_{2}$ and $50 \% \quad \mathrm{CO}_{2} / \mathrm{CO}$ (b). The relative performance of the metals differs considerably from that reported by refs. (6) and (26), possibly due to different gas atmospheres or effects of different amounts of impurities.

\section{$\underline{\text { Potential Sweeps }}$}

Like the $\mathrm{AC}$ measurements, DC polarizations revealed interesting and different behavior between the metal electrodes (Figure 6). $\mathrm{Cu}$ and $\mathrm{Ni}$ gave similar curve shapes (Ni achieving superior current density for both anodic and cathodic polarization), whereas $\mathrm{Pd}$ gave a uniquely shaped curve with greater cathodic activity than anodic activity for both $\mathrm{H}_{2} / \mathrm{H}_{2} \mathrm{O}$ and $\mathrm{CO} / \mathrm{CO}_{2}$. In $\mathrm{H}_{2} / \mathrm{H}_{2} \mathrm{O}$, the OCV measurements described above which showed that $\mathrm{R}_{\mathrm{P}}$ was lower for lower $\mathrm{pH}_{2} \mathrm{O}$ for $\mathrm{Pd}$ may explain why the activity would increase moreso during cathodic than anodic polarization. Normalized to TPB length, the Pd electrode was more active cathodically than $\mathrm{Ni}$, suggesting that $\mathrm{Pd}$ might work well as part of an electrolysis cell cathode for splitting $\mathrm{H}_{2} \mathrm{O}$ and $\mathrm{CO}_{2}$.

\section{Conclusions and Future Work}

Several metal wires were systematically characterized as model electrodes for solid oxide cells. Some notable preliminary results and interesting electrochemical phenomena unique to certain metals were summarized. Further analysis to identify the electrode ratelimiting processes and link them to reaction mechanisms is ongoing. The methods and results described appear promising to make progress towards determining the mechanisms of $\mathrm{H}_{2} / \mathrm{H}_{2} \mathrm{O}$ and $\mathrm{CO} / \mathrm{CO}_{2}$ oxidation/reduction reactions at metal-YSZ interfaces.

\section{Acknowledgments}


The authors wish to thank Jens Borchsenius, Kent Kammer Hansen, Søren Koch, Karin Vels Hansen, Nikos Bonanos, Tânia Ramos and other colleagues for discussions and technical assistance. Financial support from the American Chemical Society Petroleum Research Fund and Programme Commission on Sustainable Energy and Environment, The Danish Council for Strategic Research, via the SERC project (www.serc.dk), is gratefully acknowledged.
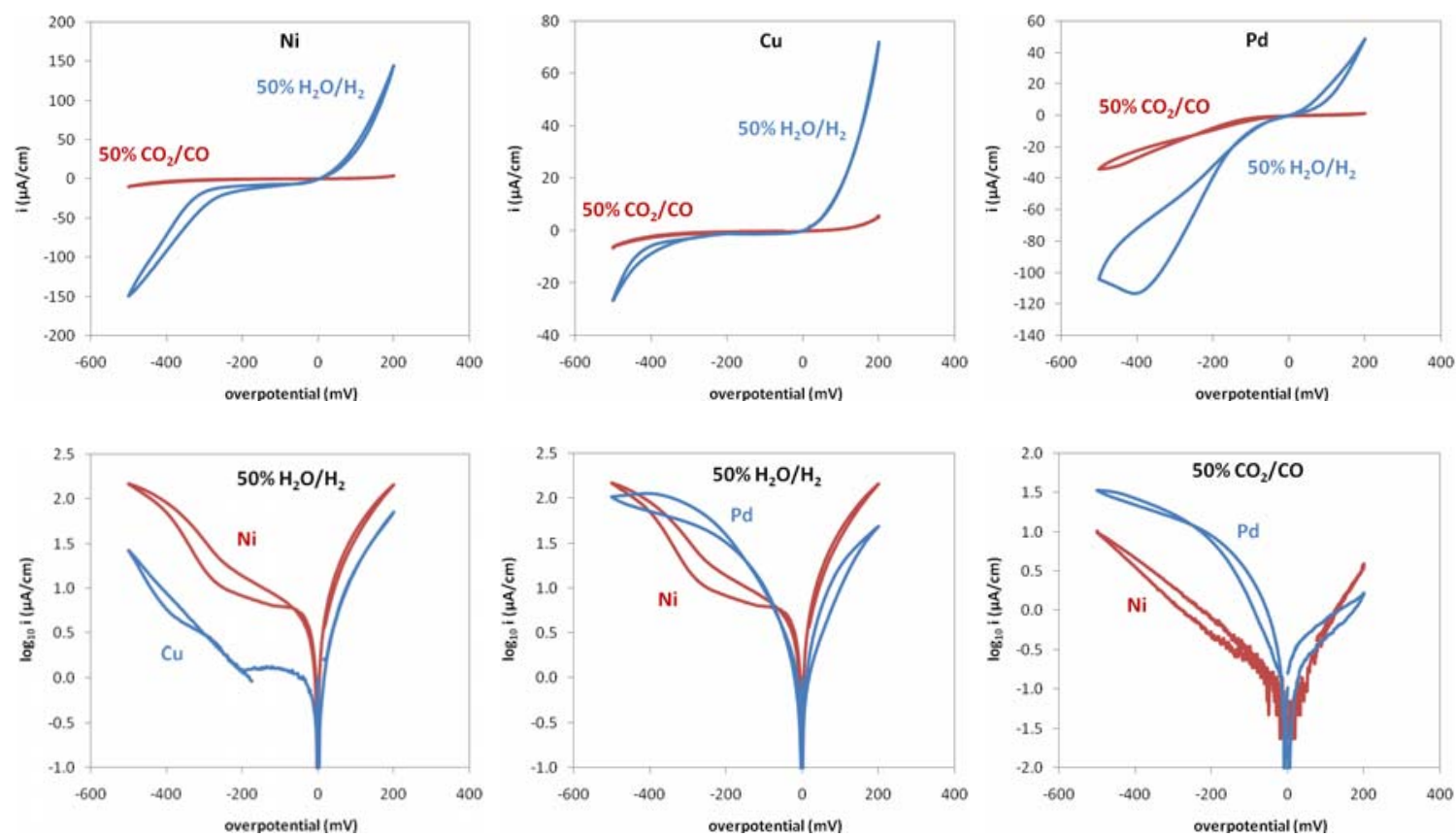

Figure 6. Potential sweeps of the $\mathrm{Ni}, \mathrm{Cu}$, and $\mathrm{Pd}$ electrodes in $\mathrm{H}_{2} \mathrm{O} / \mathrm{H}_{2}$ and $\mathrm{CO}_{2} / \mathrm{CO}$ atmospheres, at $850^{\circ} \mathrm{C}$ and $1-2 \mathrm{mV} / \mathrm{s}$.

\section{References}

1. P. Fabry and M. Kleitz, J. Electroanal. Chem., 1974. 57(2): p. 165-177.

2. M. Mogensen, J. Hogh, K.V. Hansen, and T. Jacobsen, ECS Trans., 2007. 7(1): p. 1329-1338.

3. J. Guindet, C. Roux, and A. Hammou, in Proc. of the 2nd International Symposium on SOFC. 1991. Athens, Greece. p. 553-559.

4. T. Norby, O.J. Velle, H. Leth-Olsen, and R. Tunold. in Proc. of the 3rd International Symposium on SOFC. 1993: The Electrochemical Soc. p. 473-478.

5. T. Norby. in Proc. of the 2nd European Solid Oxide Fuel Cell Forum. 1996. Oslo, Norway. p. 607-616.

6. R. Baker, J. Guindet, and M. Kleitz, J. Electrochem. Soc., 1997. 144(7): p. 2427-2432.

7. F. Z. Mohamedi-Boulenouar, J. Guindet, and A. Hammou. in Proc. of the 5th International Symposium on SOFC (SOFC-V). 1997. Pennington, NJ. p. 441-450.

8. R. J. Aaberg, R. Tunold, M. Mogensen, R.W. Berg, and R. Odegard, J. Electrochem. Soc., 1998. 145(7): p. 2244-2252.

9. R. J. Aaberg, R. Tunold, R. Ødegård, Solid State Ionics, 2000. 136-137: p. 707-712.

10. D. Kek, M. Mogensen, and S. Pejovnik, J. Electrochem. Soc., 2001. 148(8): p. A878A886.

11. K. Vels Jensen, Ph.D. thesis. 2002, Risø National Laboratory: Roskilde, Denmark. 
12. G.O. Lauvstad, R. Tunold, and S. Sunde, J. Electrochem. Soc., 2002. 149(12): p. E497-E505.

13. G.O. Lauvstad, R. Tunold, and S. Sunde, J. Electrochem. Soc., 2002. 149(12): p. E506-E514.

14. J. Høgh, Ph.D. thesis. 2005, Risø National Laboratory / The Technical University of Denmark: Roskilde, Denmark.

15. M. S. Schmidt, K. Vels Hansen, K. Norrman, and M. Mogensen, Solid State Ionics, 2009. 180(4-5): p. 431-438.

16. A. Bieberle, Ph.D. thesis. 2000, Swiss Federal Institute of Technology,: Switzerland.

17. B. Habibzadeh, A.M. Sukeshini, B. Becker, and G.S. Jackson, ECS Trans., 2008. 11(33): p. 53-61.

18. J. Mizusaki, H. Tagawa, T. Saito, T. Yamamura, K. Kamitani, K. Hirano, S. Ehara, T. Takagi, T. Hikita, M. Ippommatsu, S. Nakagawa, and K. Hashimoto, Solid State Ionics, 1994. 70-71(Part 1): p. 52-58.

19. T. Yamamura, H. Yoshitake, H. Tagawa, N. Mori, K. Hirano, J. Mizusaki, S. Ehara, T. Takagi, Y. Hishinuma, H. Sasaki, Y. Nakamura, and K. Hishimoto. in 2nd Euro. Solid Oxide Fuel Cell Forum. 1996. p. 617-625.

20. T. Yamamura, H. Tagawa, T. Saito, J. Mizusaki, K. Kamitani, K. Hirano, S. Ehara, T. Takagi, Y. Hishinuma, H. Sasaki, T. Sogi, Y. Nakamura, and K. Hashimoto. in 4th Int. Symp. Solid Oxide Fuel Cells. 1995. p. 741-749.

21. J. Mizusaki, H. Tagawa, T. Saito, K. Kamitani, T. Yamamura, K. Hirano, S. Ehara, T. Takagi, T. Hikita, M. Ippommatsu, S. Nakagawa, and K. Hashimoto, J. Electrochem. Soc., 1994. 141(8): p. 2129-2134.

22. A. de Boer, Ph.D. thesis. 1998, University of Twente: The Netherlands.

23. M. Brown, S. Primdahl, and M. Mogensen, J. Electrochem. Soc., 2000. 147(2): p. 475-485.

24. A. Bieberle and L.J. Gauckler, Zeitschrift Fur Metallkunde, 2001. 92(7): p. 796-802.

25.M. Mogensen, K.V. Jensen, M.J. Jorgensen, and S. Primdahl, Solid State Ionics, 2002. 150(1-2): p. 123-129.

26. T. Setoguchi, K. Okamoto, K. Eguchi, and H. Arai, J. Electrochem. Soc., 1992. 139(10): p. 2875-2880.

27. Y. Matsuzaki, M. Hishinuma, and I. Yasuda. in Sixth Intl Symp. on Solid Oxide Fuel Cells (SOFC-VI). 1999. Honolulu, Hawaii: Electrochemical Society. p. 560-567.

28. K. Eguchi, T. Setoguchi, K. Okamoto, and H. Arai. in Third International Symposium on Solid Oxide Fuel Cells (SOFC III). 1993. Honolulu, Hawaii: Electrochemical Society. p. 494-503.

29. K. Vels Jensen, S. Primdahl, I. Chorkendorff, and M. Mogensen, Solid State Ionics, 2001. 144(3-4): p. 197-209.

30.K. Vels Jensen, R. Wallenberg, I. Chorkendorff, and M. Mogensen, Solid State Ionics, 2003. 160(1-2): p. 27-37.

31.M.S. Schmidt, K.V. Hansen, K. Norrman, and M. Mogensen, Solid State Ionics, 2008. 179(39): p. 2290-2298.

32. M. Mogensen and K.V. Hansen, in Handbook of Fuel Cells - Fundamentals, Technology and Applications, W. Vielstich, H. Yokokawa, and H.A. Gasteiger, Editors. 2009, John Wiley \& Sons, Ltd.

33. M. Kleitz, L. Dessemond, and T. Kloid. in Proceedings of the 3rd Symposium on Solid Oxide Fuel Cells in Japan. 1994. Tokyo: The Solid Oxide Fuel Cell Society of Japan. p. 35. 
34. H. Schichlein, A.C. Müller, M. Voigts, A. Krügel, and E. Ivers-Tiffée, J. Appl. Electrochem., 2002. 32(8): p. 875-882.

35. J. Newman, J. Electrochem. Soc., 1966. 113(5): p. 501-502.

36. S. Primdahl and M. Mogensen, J. Electrochem. Soc., 1998. 145(7): p. 2431-2438.

37. S. Primdahl and M. Mogensen, J. Electrochem. Soc., 1999. 146(8): p. 2827-2833.

38. J. Rossmeisl and W.G. Bessler, Solid State Ionics, 2008. 178(31-32): p. 1694-1700. 